DOI 10.35433/ISSN2410-3748-2019-1(24)-8

І.О. Пойта, к.е.н., доцент

кафедри економіки, менеджменту та маркетингу, М.О. Горик-Чубатюк, асистент

кафедри економіки, менеджменту та маркетингу, Житомирський державний університет імені Івана Франка

\title{
ХАРАКТЕРИСТИКА МАРКЕТИНГОВОЇ ЛОГІСТИКИ В СИСТЕМІ УПРАВЛІННЯ ПІДПРИЕМСТВОМ
}

В статі розглянуто основні аспекти та визначено перспективи розвитку маркетингової логістики. Наведено основні завдання логістичної системи та ї̈ місце в комплексі маркетингу . Обтрунтовано та систематизовано понятійний апарат маркетингової логістики. Визначено порівняльну характеристику елементів конщепції "7-P» (price product-promotion -place - people - process - physical evidence», щэо стали основою

функціонування маркетингової логістики. Зазначено, щуо максимізувати ефект забезпечення конкурентної переваги підприємства на ринку можна лише у результаті інтеграції маркетингу та логістики. Це зумовлено тим, що взаємодія маркетингу, орієнтованого на ринок, і логістики, орієнтованої на потік, створює можливості для підвищення товарної та інформаційної корисності, а також иүінності товарів для споживачів.

Ключові слова: маркетинг, логістика, комплекс маркетингу,логістичний підхід, транспортнологістичні технологї, крос-докінг, маркетингова логістика.

\section{CHARACTERISTICS OF MARKETING LOGISTICS IN THE MANAGEMENT SYSTEM OF ENTERPRISE}

The article considers the main aspects and defines the prospects for the development of marketing logistics. The main tasks of the logistics system and its place in the marketing complex

are presented. The conceptual apparatus of marketing logistics is substantiated and systematized. The comparative characteristics of the elements of the concept of "7-P" (priceproduct-promotion-place -people - prcess - physical eidence), which became the basis of the functioning of marketing logistics, were determined. It is noted that maximizing the effect of ensuring the competitive advantage of an enterprise on the market can be achieved only as a result of integration marketing and logistics, due to the fact that market-oriented marketing and flow-oriented marketing logistics create opportunities for increasing product and information value, as well as value of goods for consumers.

Key words: marketing, logistics, marketing complex, logistic approach, transport logistics technologies, cross-docking, marketing logistics. 
Постановка проблеми. За сучасних умов функціонування бізнесу важливою проблемою постає не лише доставка вантажів, а й обслуговування та сервіс. Логістика забезпечує просування вантажопотоку від виробника до споживача, проте існує ймовірність псування товарних одиниць, їх повернення та необхідність заміни, тому постає необхідність використання принципів та методів маркетингу, які забезпечують якісний, сучасний сервіс та обслуговування.

Маркетингова логістика $\epsilon$ сферою, яка безпосередньо стосуються обслуговування клієнта через ідентифікацію і виконання його потреб. Бажання задовольнити зростаючі потреби клієнтів стає причиною значного розвитку логістики і маркетингу, що одночасно впливає на спосіб управління ланцюгом поставок.

Аналіз останніх досліджень і публікацій. Проблемам розвитку, аналізу тахарактеристикам маркетингової логістики приділяли увагу такі закордонні науковці: Д. Дж. Бауерсокса, М. Бернон, Д. Вордлоу, Д. Вуда, П. Гембл, Дж. Джонсона, П. Діксон, Р. Каплан, Ф. Котлер, Д.Дж. Клоса, М. Крістофера, Р. Купер, К. Мартін, П. Мерфімол., Д. Ламберта, М. Ліндерса, Х. Пека, Д. Стока, Д. Уотерс, Р. Хоук, А. Харрісон, Х. Фірона, З. Фегель та вітчизняні науковці: Л. Балабанова, Г. Бачинський, О. Біловодська, О. Будрин, О. Варєс, O. Варченко, А. Гаджинського, П. Гайдуцький, Б. Губський, А. Голіков, М. Григорак, А. Даниленко, М. Каховська, Д. Іванов, С. Крикавський, М. Малік, Л. Міротіна, Ю. Неруша, М. Окландер, О. Перебийніс, А. Плотников, О. Поспєлов, Ю. Пономарьов, П. Саблук, О. Струк, Л. Фролова, Н. Чухрай. Проте проведенні дослідження потребують систематизації та обгрунтування маркетингової логістика як суцільної системи.

Постановка завдання. Метою даної статті є аналіз та систематизація існуючих концепцій маркетингу i логістики i інтегровану систему маркетингової логістики

(C) Пойта I.О., Горик-Чубатюк М.О. 
Виклад основного матеріалу. Сучасна логістична система забезпечує переміщення вантажів (матеріалів, товарів, сировини тощо) від виробника (постачальника) до споживача за участю спеціалізованих учасників процесів просування та обслуговування вантажопотоку (обробка замовлень, формування партій товарів, транспортування, складування, навантаження, перевантаження, пакування, перепакування, логістичного сервісу тощо). Тому важливими іï завданнями є:

1) доставка вантажів в найшвидші терміни,

2) збереження якості переміщуваних товарів,

3) найменший рівень затрат всіх логістичних процесів,

4) тотальний контроль та мобільність виконання,

5) найшвидша обробка замовлень,

6) оптимальне формування логістичних ланцюгів.

Логістичний підхід до організації бізнесу орієнтований на розвиток постачань споживачам товарів на принципах «точно в термін», «від дверей до дверей» на основі використання наскрізних транспортнологістичних технологій вода-повітря-земля та додаткових сервісних: різні види зберігання, крос-докінг та інше [7, с. 123].

Сучасний маркетинг забезпечує вивчення, аналізування та прогнозування ринкових потреб у тому, чи іншому товарі, що дозволяє змоделювати конкретну величину необхідності у продукції. На основі чого, логістичний підхід сформує партію товарів, що перетворить на матеріальний потік та почне просувати по логістичному ланцюзі. У разу, якщо в логістичній системі товар прибуде невчасно, або будуть похибки у місці призначення, часі тощо, то застосування маркетингових заходів дозволить сформувати попит на продукцію та про стимулювати збут (застосування різних видів реклами, промоушен-заходів та ін.).

Маркетинг є невід'ємною частиною загальної логістичної системи підприємства, охоплюючи весь ланцюг системи розподілу: маркетинг, (C) Пойта I.О., Горик-Чубатюк М.О. 
транспортування, складування. Вона може бути охарактеризована двовекторно:

- як вивчення потреб ринку (цим власне і займається маркетинг);

- як способи і методи найбільш повного задоволення цих потреб [4, c. 35].

Таким чином в сучасному управління підприємствами, встановленні торгівельних зв’язків, переміщенні вантажів, особливого значення набуває таке поняття, як «маркетингова логістика», що виступає синтезом маркетингу та логістики.

Вивчення позицій науковців щодо розуміння понять «маркетинг» та «логістика» та їх систематизація дозволяє запропонувати власне визначення поняття «маркетингової логістики» як системи оптимізації об’єднання матеріальних, інформаційних і фінансових потоків, при якій доставка товару (надання послуги) здійснюється у потрібній кількості, якості й асортименті в потрібний час i потрібне місце за прийнятною ціною 3 мінімальними витратами, кінцевим результатом якої $\epsilon$ максимальний прибуток від діяльності всіх ланок логістичного ланцюга і соціальний ефект. Таким чином, сфера використання маркетингової логістики - це стадія фізичного розподілу продукції, де відбувається рух товарів від виробника до його ринків збуту [3].

Г.А. Плахута та I.В. Попова визначають маркетингову логістику як діяльність щодо планування, виконання та контролю фізичного переміщення всіх видів потоків (матеріалів, готової продукції, інформації), які супроводжують переміщення товару за вибраним каналом від виробника до споживача з метою задоволення потреб споживачів та отримання прибутку $[10$, c. 146$]$.

Ф. Котлера, маркетингова логістика об’єднує планування, впровадження та контроль матеріальних потоків, починаючи 3 пунктів походження i закінчуючи пунктами призначення з метою задоволення потреб покупців [6]. 
М. Крістофер, один 3 основоположників поняття «маркетингова логістика», у своїх працях не наводить єдиного точного визначення, проте зазначає, що маркетингова логістика зосереджується на тому, як саме обслуговування клієнтів можна використати для здобуття конкурентних переваг. Вона спрямована також на керівництво взаємодією між маркетингом i логістикою 3 метою узгодження перспективних стратегій в контексті ширшого ланцюга поставок [1]. Поширена формула «маркетинг формує попит, а логістика його реалізує» [5, с. 363].

Характеристика складових маркетингової логістики, що увібрала в себе окремі елементи логістики та маркетингу, представлена у таблиці 1.

Таблиця 1

Характеристика складових маркетингової логістики

\begin{tabular}{|c|c|c|}
\hline \multirow[t]{2}{*}{$\begin{array}{c}\text { Маркетингова } \\
\text { логістика }\end{array}$} & Логістика & $\begin{array}{l}\text { - доставка вантажів, } \\
\text { - складання графіків перевезень, } \\
\text { - формування вантажопотоку, } \\
\text { - матеріально-технічне забезпечення логістичного } \\
\text { ланцюга, } \\
\text { - взаємодія логістичної системи, } \\
\text { - складування та зберігання, } \\
\text { - облік та управління запасами, } \\
\text { - упаковка та тара, } \\
\text { - контроль та якість. }\end{array}$ \\
\hline & Маркетинг & $\begin{array}{l}\text { - дослідження та аналіз ринку, } \\
\text { - прогнозування розвитку та номенклатури, } \\
\text { - формування попиту, } \\
\text { - стимулювання збуту, } \\
\text { - рекламні заходи та акції, } \\
\text { - дослідження конкурентоспроможності. }\end{array}$ \\
\hline
\end{tabular}

Джерело: Складено авторами на основі власних розробок

Таким чином, маркетингова логістика синтезувала у собі найкращі елементи маркетингу та логістики, що дозволяє підняти якість виконання логістичних послуг, завдяки маркетинговому сервісу, на найвищий рівень виконання.

Інтеграція маркетингу i логістики на стадіях, що передують безпосередньому процесу виробництва передбачає зміну підходу до (C) Пойта I.O., Горик-Чубатюк М.O. 
закупівельної діяльності. На цьому етапі управління матеріальними потоками виникає необхідність приймати рішення, які максимально повинні задовольняти суперечливі інтереси підприємств-постачальників, транспортних підприємств і організацій, а також складських і виробничих підрозділів підприємств споживачів [2, с. 84-88].

Взаємодія маркетингу та логістики в рамках конкретних організацій часто розглядається з точки зору, згідно якої логістика сприймається як друга половина маркетингу. Це стає можливим завдяки тому, що зв'язки між цими напрямки діяльності підприємства часто настільки сильно переплетені, що іноді буває важко розділити сфери інтересів цих ключових функцій будь якого бізнесу, в тому числі і малого [8].

Маркетингово-логістичний підхід:

1) зорієнтований на максимальне задоволення потреб споживачів шляхом, з одного боку, всебічного дослідження ринку, вивчення попиту споживачів (їх вподобань і потреб), а з іншого - за рахунок формування потреб та бажань споживачів, визначення майбутніх ринкових потреб;

2) реалізується на основі впровадження комплексу маркетингових засобів та інструментів, що відображені в концепції «7-Р» та включають такі групи, як товар, ціна, місце, просування, корпоративна філософія, бізнес процеси і персонал;

3) грунтується на правильному позиціонуванні та успішному впровадженні товару (послуги) на ринок, а також створенні ефективної бізнес-моделі та формуванні сегменту лояльних споживачів [11].

Характеристика елементів концепції «7-Р» (price - product - promotion place - people - process - physical evidence», що стали основою функціонування маркетингової логістики, представлено у таблиці 2. 
Таблиця 2

Характеристика елементів концепції «7-Р».

\begin{tabular}{|c|c|c|}
\hline $\begin{array}{c}\text { Елементи } \\
\text { концепції } \\
\text { «7-Р» }\end{array}$ & Характеристика дії маркетингу & Характеристика дії логістики \\
\hline 1 & 2 & 3 \\
\hline $\begin{array}{l}\text { Ціна } \\
\text { (price) }\end{array}$ & $\begin{array}{l}\text { Основною метою, } 3 \text { позицій } \\
\text { маркетингу, є залучення різних } \\
\text { сегментів ринку, за допомогою } \\
\text { цін, яке забезпечує загальне, } \\
\text { економічне і п психологічне } \\
\text { сприйняття товару потенційним } \\
\text { споживачем, } \\
\text { конкурентні переваги товару. }\end{array}$ & $\begin{array}{l}\text { Всі логістичні процеси (складування, } \\
\text { транспортування, пакування та ін.) } \\
\text { переносять свою вартість на } \\
\text { формування остаточної ціни. Тому } \\
\text { основна мета покладена на зменшення } \\
\text { витрат. }\end{array}$ \\
\hline $\begin{array}{l}\text { Продукт } \\
\text { (product) }\end{array}$ & 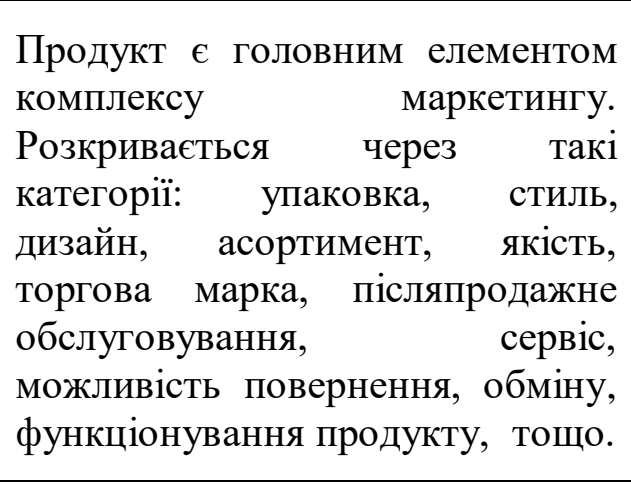 & $\begin{array}{l}\text { Головним завданням логістики } \\
\text { формування } \\
\text { товарів, логістичного потоку } \\
\text { перевантажуються, транспортуються та } \\
\text { iн. зі збереженням належної якості. } \\
\text { Тому важливо вивчити взаємодію } \\
\text { товарної номенклатури, визначити } \\
\text { правильні способи транспортування та } \\
\text { зберегти якість товару на найвищому } \\
\text { рівні. }\end{array}$ \\
\hline $\begin{array}{c}\text { Просування } \\
\text { (promotion) }\end{array}$ & 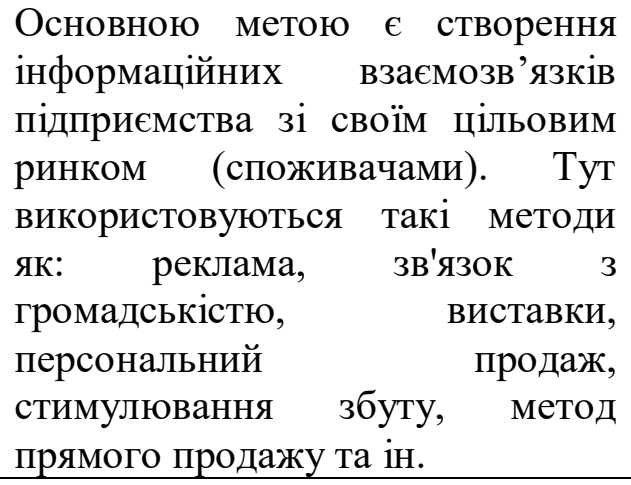 & $\begin{array}{llr}\text { Формування, доставка та розподіл } \\
\text { вантажів мають виконуватися в } \\
\text { найменші строки. Тому основне } \\
\text { логістичне } \text { завдання полягає } \\
\text { просуванні матеріальних потоків } \\
\text { найбільшою швидкістю від виробника } \\
\text { до споживача. }\end{array}$ \\
\hline $\begin{array}{l}\text { Розмішення } \\
\text { (place) }\end{array}$ & $\begin{array}{l}\text { Основною метою є забезпечення } \\
\text { доставки товару цільовій групі } \\
\text { споживачів у потрібне місце і } \\
\text { час. Його характеризують такі } \\
\text { категорії: канали розподілу } \\
\text { (збуту), посередники, рівні збуту, } \\
\text { транспортування, складський } \\
\text { запас, розміщення, підготовка } \\
\text { торгового персоналу та ін. }\end{array}$ & $\begin{array}{l}\text { Оптимальне формування розподільчих } \\
\text { пунктів та складських приміщень } \\
\text { дозволяє правильно розміщувати } \\
\text { вантажі. Тому логістика призначена } \\
\text { управляти логістичним ланцюгом та } \\
\text { впливати на учасників його руху } \\
\text { точним визначенням: де саме, як саме, } \\
\text { коли саме розміщується той чи інший } \\
\text { вантаж. }\end{array}$ \\
\hline
\end{tabular}


Продовження таблиці 2

\begin{tabular}{|c|c|c|}
\hline 1 & 2 & 3 \\
\hline $\begin{array}{c}\text { Люди } \\
\text { (people) }\end{array}$ & $\begin{array}{l}\text { Маркетинг відносин, } щ о ~ \\
\text { забезпечується в } \quad \text { процесі } \\
\text { розробки кадрової } \text { політики } \\
\text { підприємства (підбір і навчання } \\
\text { персоналу, орієнтованого на } \\
\text { клієнта і цілі фірми), формування } \\
\text { потенційних клієнтів. }\end{array}$ & 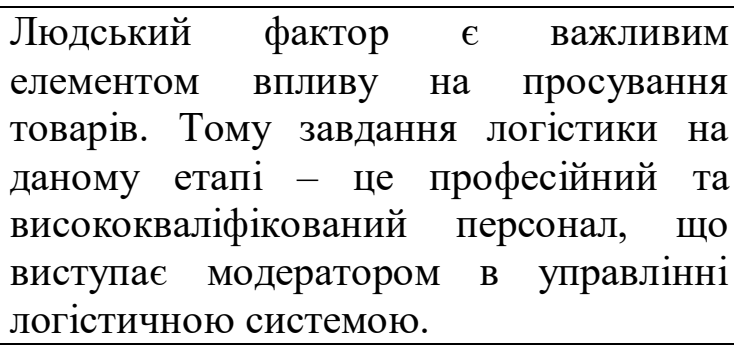 \\
\hline & 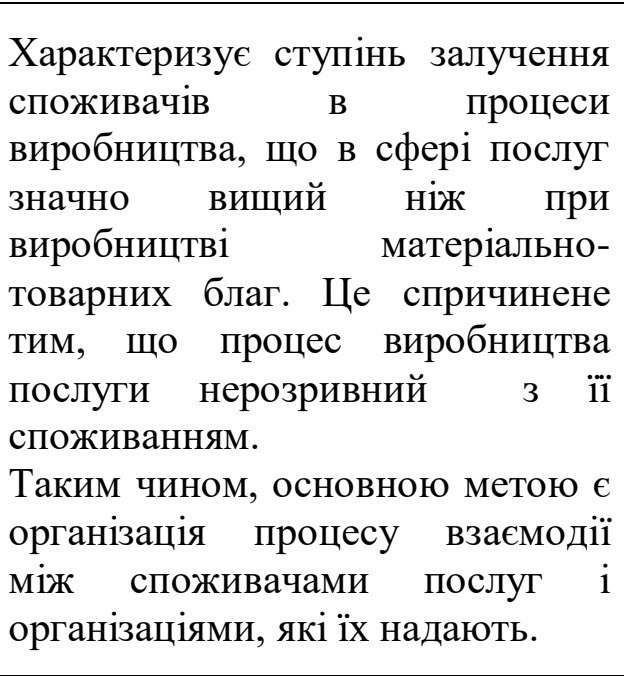 & 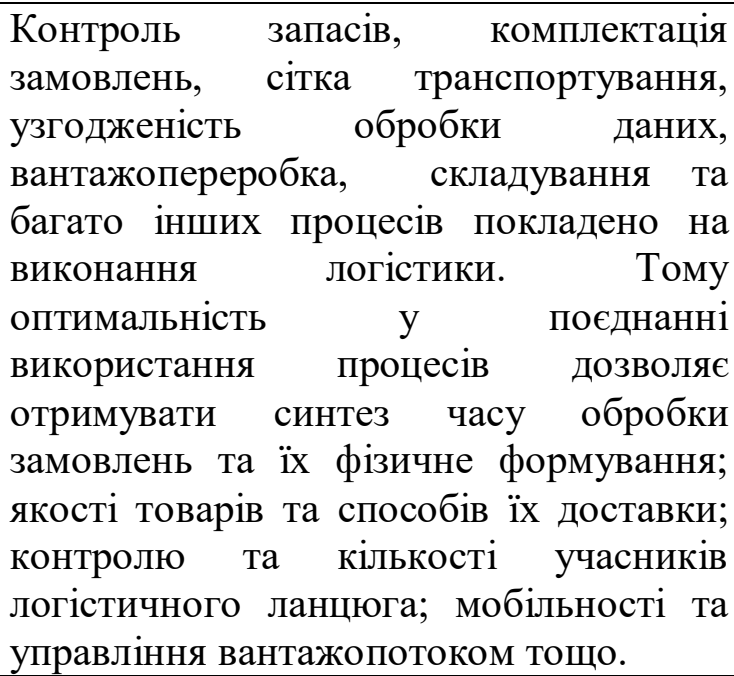 \\
\hline $\begin{array}{c}\text { Фізична } \\
\text { наявність } \\
\text { (physical } \\
\text { evidence) }\end{array}$ & $\begin{array}{l}\text { Включає в себе всі матеріальні } \\
\text { блага і візуальні образи, які } \\
\text { дозволяють } \\
\text { споживачеві потенційному } \\
\text { спрогнозувати якість майбутньої } \\
\text { послуги. Основною метою є } \\
\text { формування } \\
\text { позитивного іміджу в очах своїх } \\
\text { споживачів. Для досягнення } \\
\text { цього підприємствам необхідно } \\
\text { постійно вдосконалювати рівень } \\
\text { сервісу і якість обслуговування } \\
\text { своїх клієнтів. }\end{array}$ & 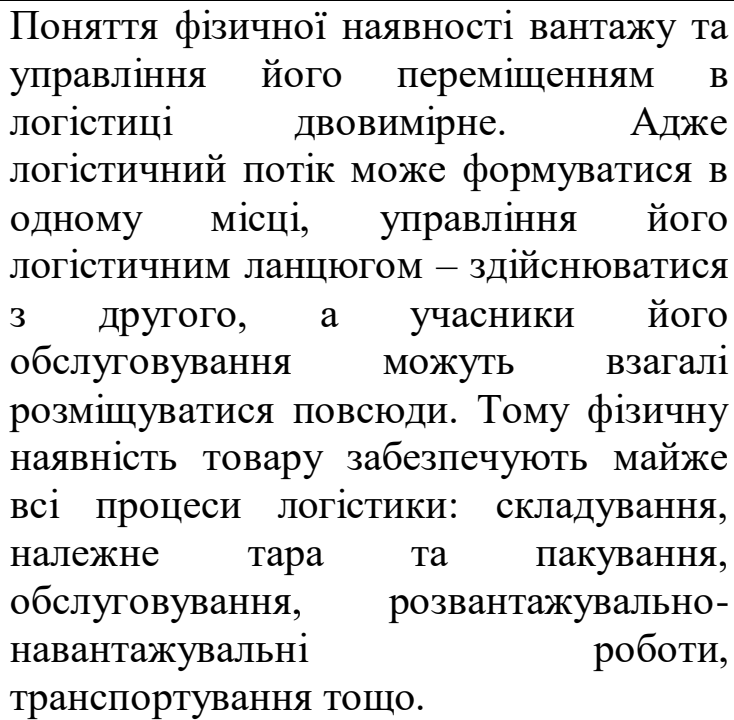 \\
\hline
\end{tabular}

Джерело: Складено авторами на основі власних розробок

Отже, маркетинговій логістиці концепція «7-Р», 3 боку логістичної системи забезпечує: доставку необхідного товару, в необхідній кількості, в конкретно заданому місці, точно в заданий термін, 3 необхідною швидкістю вантажообробки, 3 інформаційною прозорістю та доступністю, 3 дотриманням безпечності транспортування та збереженості вантажів, 
надаючи регулярності та надійності доставки, а також виконання в найменші строки, зі збереженням відповідної якості, гнучкість та мобільність; з боку маркетингу: забезпечує виробництво та продаж найкращого для споживача товару, з його унікальними характеристиками, за найоптимальнішою ціною та способом купівлі (доставки), у потрібний час, 3 умовою ефективного обслуговування та сервісу.

Комплексність i синхронність, що лежать в основі маркетингу i логістики, покладені в основу алгоритму побудови маркетингової системи логістики [8, с. 89-96]:

- розгляд руху і зберігання матеріалів і товарів від первинного джерела до кінцевого споживача як єдиного матеріального потоку;

- впровадження логістичної системи - як засіб реалізації концепції маркетингової логістики;

- використання агрегованого показника ефективності функціонування маркетингової системи логістики, який крім затрат, пов’язаних 3 матеріальним потоком, враховує втрати прибутку внаслідок невикористаних (втрачених) можливостей, а також затрат, обумовлених вмістом матеріальних запасів.

В ході побудови системи маркетингової логістики важливе:

- розуміння i виконання вимог до забезпечення якості випущеної продукції і закупівельних ресурсів;

- необхідність розгляду процесів 3 точки зору створення додаткових цінностей як для підприємства, так і для проміжних і кінцевих споживачів;

- вимірювання результатів функціонування процесу і його ефективності;

- постійного вдосконалення процесів на основі ефективних вимірювань $[9$, c. 67].

Висновки та пропозиції. Ефективна маркетингова логістика в сучасних умовах конкурентного ринку та євроінтеграції можлива за умови дотримання концептуальних принципів:

(C) Пойта I.O., Горик-Чубатюк М.O. 
- системного підходу, інтеграції спеціалізованих виробництв у виробничотранспортні, виробничо-транспортно-складські, функціональні системи єдиної технології;

- гнучкість технологічних ланцюжків, високої надійності і якості функціонування системи;

- надійність та саморегуляція;

- економічність;

- моделювання товарообороту;

- облік сукупних недоліків виробництва по всьому логістичному ланцюжку з орієнтацією на ринок;

- розвиток сервісу на сучасному рівні;

- зворотній зв'язок, в якості якого виступає попит споживача, що визначає в кінцевому підсумку стратегічні цілі функціонування [8, с. 89-92].

Таким чином, максимізувати ефективність діяльності, підвищити рівень конкурентоспроможності підприємства можливо лише за умови систематизації та інтеграції маркетингу і логістики. Це пояснюється тим, що взаємодія маркетингу, орієнтованого на ринок, і логістики, орієнтованої на потік, створює можливості для підвищення товарної та інформаційної корисності, а також цінності товарів для споживачів. В сучасних умовах економіка створює переважно сприятливі умови для ефективного та комплексного застосування логістики i маркетингу в різних сферах, що зумовлено низкою якісних змін соціально-економічних процесів.

\section{Список використаних джерел:}

1. Christopher M. Marketing Logistics / M. Christopher, H. Peck. - Second Edition. - Oxford : Elsevier Butterworth-Heinemann, 2003. - 168 p.

2. Варес А.Ю. Маркетинговая логистика / А.Ю. Варес, С.С.Вострецов // Вісник Харківського національного університету ім. В.Н. Карамзіна - 2001. №535 - C. 84-88.

(C) Пойта I.O., Горик-Чубатюк М.O. 
3. Васюк І.В. Роль маркетингової логістики в процесі функціонування підприємства / I.В. Васюк // Збірник наукових праць Національного університету державної податкової служби України. - 2011. - № 1. -С. 93100.

4. Гордон М.П. Функции и развитие логистики в сфере товарообращения / М.П. Гордон // РИСК - 2003. - № 1. - с. 35-45.

5. Капустин С.Н. Современные технологии управления для оптимизации бизнеса компании / С.Н. Капустин. - М.: ИД «Дашков и К», 2013. $-547 \mathrm{c}$.

6. Котлер Ф. Маркетинг менеджмент / Ф. Котлер; [пер. с англ.]. - 11-е изд.; - СПб.: Питер, 2005. - 800 с.

7. Кузьменко А.В. Сутність маркетингу та логістики в діяльності підприємств / А.В. Кузьменко // Вісник економіки транспорту і промисловості. - 2013. - № 43. - С. 203-209.

8. Левицкий С.И. Моделирование финансовой деятельности предприятия методом системной динамики / С.И. Левицкий // Сборник статей ["Модели управления в рыночной экономике"]. - Донецк: ДонНУ, 2001. - C.89-96.

9. Окландер М.А. Проблеми формування маркетингової системи країни / М.А. Окландер - К.: Наук. думка, 2002. - 168 с.

10. Плахута Г.А. Інтеграція маркетингу i логістики в системі менеджменту / Г.А. Плахута, І.В. Попова // Маркетинг: теорія і практика: зб. наук. праць Східноукраїнського національного університету імені Володимира Даля. - 2008. - Вип. 14. - С. 145-148.

11. Черноусов Е.В. Анализ рынка логистических провайдеровзарубежный опыт / Е.В. Черноусов // Менеджмент в России и за рубежом. 2008. - № 6. - C. 13-17. 


\section{REFERENCES:}

1. Christopher M. (2003). Marketing Logistics [Marketing Logistics]. Oxford : Elsevier Butterworth-Heinemann [in English].

2. Vares A.Yu. \& Vostretsov S.S. (2001). Marketynhovaia lohystyka [Marketing logistics]. Visnyk Kharkivskoho natsionalnoho universytetu im. V.N. Karamzina, 535, 84-88 [In Russian].

3. Vasiuk I.V.(2011). Rol marketynhovoi lohistyky $\mathrm{v}$ protsesi funktsionuvannia pidpryiemstva [The role of marketing logistic in the process of func- tioning the company]. Zbirnyk naukovykh prats Natsionalnoho universytetu, 1, 93-100 [In Ukrainian].

4. Hordon M.P. (2003). Funktsyy y razvytye lohystyky v sfere tovaroobrashchenyia [Functions and development of logistics in the field of commodity circulation]. RYSK, 1, 35-45 [In Russian].

5. Kapustyn S.N. (2013). Sovremennыe tekhnolohyy upravlenyia dlia optymyzatsyy byznesa kompanyy [Modern management technologies to optimize the company's business]. YD «Dashkov y K» [In Russian].

6. Kotler F. (2005) Marketynh menedzhment [Marketing management]. 11-e yzd.; SPb.: Pyter [In Russian].

7. Kuzmenko A.V. (2013). Sutnist marketynhu ta lohistyky v diialnosti pidpryiemstv [The essence of marketing and logistics in the activities of enterprises ]. Visnyk ekonomiky transportu i promyslovosti, 43, 203-209 [In Ukrainian].

8. Levytskyi S.Y. (2001). Modelyrovanye fynansovoi deiatelnosty predpryiatyia metodom systemnoi dynamyky [Modeling of financial activity of an enterprise using the system dynamics method]. Donetsk: DonNU [In Russian].

9. Oklander M.A. (2002). Problemy formuvannia marketynhovoi systemy krainy [Problems of the formation of the country's marketing system]. K.: Nauk. Dumka [In Ukrainian].

10. Plakhuta H.A. \& Popova I.V. (2008) Intehratsiia marketynhu i lohistyky v systemi menedzhmentu [Integration of marketing and logistics in the (C) Пойта I.O., Горик-Чубатюк М.O. 
management system ]. Marketynh: teoriia i praktyka: zb. nauk. prats Skhidnoukrainskoho natsionalnoho universytetu imeni Volodymyra Dalia, 14, 145-148 [In Ukrainian].

11. Chernousov E.V. (2008). Analiz rynka logisticheskikh provayderovzarubezhnyy opyt [Analysis of the market of logistics providers - foreign experience]. Menedzhment v Rossyy y za rubezhom, 6, 13-17 [In Russian]. 